\title{
"It's Not Human!”: Another Example of Anthropodermic Bibliopegy Discredited
}

In January 2016, the University of Memphis Libraries (UML) announced that the "human skin book" held in the Preservation and Special Collections Department for 30 years did not have an anthropodermic binding after all. ${ }^{1}$ The results of new scientific testing were a disappointment to some library staff because the book had become an object of fascination for many students and its fame had spread far beyond the campus. The story of how one book came to symbolize the archives and the library of the University of Memphis is an interesting one. However, there are also important questions about the way a relic is used and exploited to attract more patrons to libraries and archives, and the ethical considerations that accompany such use.

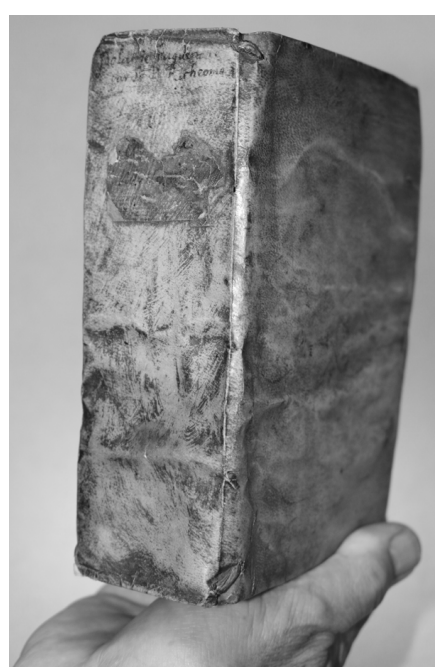

Image 1. Binding of the UML copy of Richeome's L'Idolatrie Huguenote.

\section{The Book and Its Author}

In 1608, the French Jesuit Louis Richeome published his anti-Protestant polemic, L'Idolatrie $\mathrm{Hu}$ guenote Figurée au Patron de la Vieille Payenne, Divisée en Huit Livres \& Dediée au Roy Tres Chrestien de France \& de Navarre Henri IIII. Richeome was born in Digne in 1544 and joined the Society of Jesus in Paris in 1565 . He went on to hold teaching posts in Bordeaux, the University of Pont-à-Mousson, and Dijon, where he founded a college. He served as provincial at Lyon and Aquitaine and was the French assistant to the Superior General of the order in Rome from 1606 to $1616 .{ }^{2}$ Richeome was then appointed to a senior post in Lyon before returning to teaching in Bordeaux. He died there on September 15, 1625.

1. University of Memphis Libraries, Between the Stacks 5 (Jan. 2016).

2. For some insight into Richoeme's work in France and Rome on behalf of the Jesuit order, see Eric Nelson, "The King, the Jesuits and the French Church, 1594-1615" (DPhil diss., University of Oxford, 1998), available online at https: / / ora.ox.ac.uk/objects/uuid:78447dd8-1dbb-4a2f-8aee-f964c293faa9 [accessed 15 September 2016].

*C 2017 by Gerald Chaudron (CC BY-NC [https://creativecommons.org/licenses/by-nc/4.0/]). 
L'Idolatrie Huguenote was but one of a stream of theological polemics and other publications by Richeome writing as an early Christian humanist but mostly as an anti-Calvinist, and, because of his elegant style, contemporaries dubbed him the French Cicero. ${ }^{3}$ He lived during a period in France when the power of the Jesuits was growing but Catholicism felt threatened by the large minority of Huguenots (Calvinists) in the country; this led to intermittent warfare between the two groups from the 1560s. Further inflaming Catholic fears was the ascension of a Huguenot, Henry IV, to the French throne in 1589. Henry had fought against Catholics in the French wars of religion but found it politic to give up his Calvinist faith to take control of the country. French Protestants were given substantial rights by the Edict of Nantes issued by Henry in 1598; this effort to promote civil unity ended the religious wars but left many disaffected Catholics, one of whom assassinated Henry in 1610 .

Richeome's "Idolatry of the Huguenots" attempted to prove once and for all that Calvinism was the work of the Devil by exposing the spiritual idolatry of the Protestants. To explain this invisible, and therefore more dangerous, heresy, the book was written as a treatise about pagan images and how they were linked to Calvinist heresy. The book was well received by Catholic apologists, and a Latin version was published five years later for use in Germany, but the Calvinist minister Jean Bansilion responded with an analysis of Richeome's argument called L'Idolatrie papistique in 1609, which effectively demolished it. In Richeome's next book, Le Panthéon Huguenot (1610), he forwent imagery for doctrine. ${ }^{4}$

\section{Provenance}

Until UML Special Collections was offered the opportunity in 2015 to test whether its copy of L'Idolatrie Huguenote was bound in human skin, as it had claimed for three decades, little work had been done to ascertain its provenance. While the curator of the department, Edwin G. Frank, was deciding whether to agree to the test, he asked UML cataloging librarian Dr. Linde Brocato, who has expertise in rare books, to examine the book. The existing documentation in the book's case file was meager and did not even contain a detailed description of the physical object. Brocato's report began with the basics: the volume is a small octavo with a sewn-in title page, and the binding is $17 \times 11 \mathrm{~cm}$ with a $0.8 \mathrm{~cm}$ circuit edge, and the text block is $16.3 \times 10.6 \mathrm{~cm}$ and $5.3 \mathrm{~cm}$ deep. The title page features an allegorical

3. Anthony Ossa-Richardson, "Image and Idolatry: The Case of Louis Richeome," in Method and Variation: Narrative in Early Modern French Thought, eds. Emma Gilby and Paul While (Oxford: Modern Humanities Research Association and Maney Publishing, 2013), 42. Richeome's books on the visual arts were so highly regarded in his time, and subsequently, that he is considered one of the three most important Jesuit writers of the early modern era on the subject. Francis de Sales and Adrien Gambart, "Visual, Verbal, Mental, and Living Images in Modern Catholicism," Journal of Religion \& $\sigma$ Society Supplement Series, Supplement 8 (2012): 58.

4. Ossa-Richardson, "Image and Idolatry," 43-48, 51. 
engraving by Jacques de Fornazeris and names the publisher as Pierre Rigaud of Lyon. Brocato found that the book is not especially rare, with copies held in libraries in the United States and Europe. ${ }^{5}$ Looking at the binding itself, it was obvious to Brocato that the limp parchment with circuit edges and the remains of twisted thong ties was not original. Evidence of rebinding included ink stains in the text and at the head and outside margins that had been cropped when the text block was trimmed to fit the binding. She suggested the book may have been rebound in the seventeenth or eighteenth century because the original had deteriorated or sustained damage. ${ }^{6}$

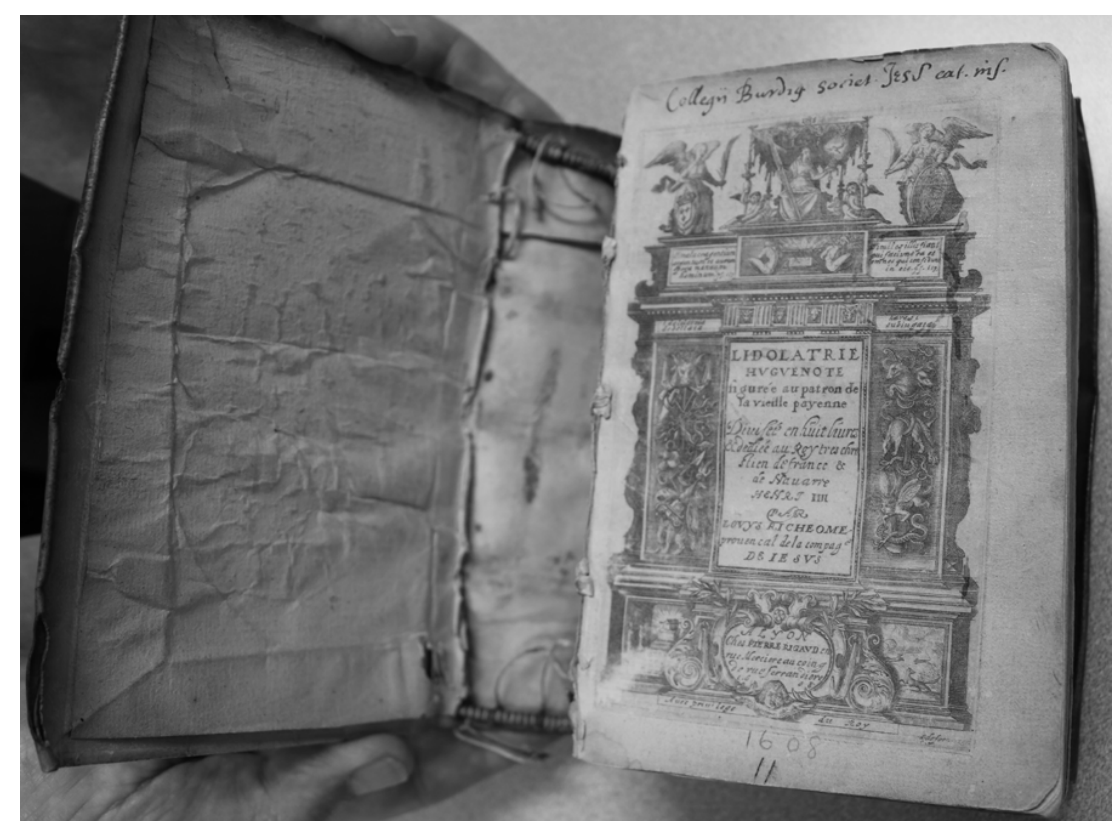

Image 2. Title page of the UML copy of L'Idolatrie Huguenote and spine foldovers from where the 2015 test samples were taken.

The only evidence of ownership in the book is a handwritten line at the top of the title page, which reads "Collegii Burdig[alae] societ[atis] Jes[u] S cal. ins." This suggests the book was possibly in the library of the Jesuit Collège de la Madeleine in Bordeaux at one point. There is nothing else that points to the book's provenance before it was acquired by UML. The story of how the University of Memphis obtained the book was recorded in a note in the book's case file written by Ed Frank just before his retirement in 2015. Frank was told by one of his predecessors, soon

5. A digitized copy is available from the Bayerische Staatsbibliothek at http:/ / reader.digitale-sammlungen.de/resolve/display/bsb10776095.html, but the engraving differs in a number of ways from the UML copy, although it too was a Rigaud imprint from 1608.

6. Linde Brocato, "Report on Richeome's L'Idolatrie Huguenote ..." (July 1, 2015), UML Special Collections case file. Brocato's findings confirm those of a Baylor University researcher who examined the book in 2013. Perry Harrison, "On the Binding of the University of Memphis' L'Idolatrie Huguenote," Notes and Queries 62, no. 4 (2015): 590. 
after he started work in the department toward the end of 1986, that the book had been found in an antiquarian bookshop in Paris in the late 1940s or early 1950 s by a prominent Memphis cotton merchant, Berry Brooks. ${ }^{7}$ Assured by the store owner that the book was bound in human skin, Brooks purchased the volume and brought it back to Memphis. ${ }^{8}$

Some years after Brooks' death in January 1976, Burke’s Book Store, an antiquarian book dealer in Memphis, bought the Richeome book from the estate. The UML curator of Special Collections at the time was well known to Burke's owner, Diana Crump, who offered the book to her. UML asked for proof that the binding was anthropodermic and was prepared to pay to have it tested. ${ }^{9}$ Crump contacted Jerold M. Lowenstein, Clinical Professor of Medicine at the University of California, San Francisco, to have the binding tested using the radioimmunoassay technique. First developed by Rosalyn Yalow and Solomon A. Berson in 1959, the test employs radioactive isotopes to measure tiny amounts of a substance in the blood and is now used for drug and cancer detection, screening for hepatitis, and research of neurotransmitters in the brain. Lowenstein was a pioneer in the field of nuclear medicine and used his knowledge to focus on fossil molecules and the detection of proteins in extinct species and early man. ${ }^{10}$ In a letter reporting the results of his test on a fragment of the binding supplied by Burke's, Lowenstein said he had identified three proteins — collagen, fibronectin, and transferrin — and used appropriate antisera to determine whether the proteins were human or bovine. Confusingly, he defined bovine as "either calfskin or sheepskin." Dr. Lowenstein declared: "All three proteins reacted as human rather than bovine. Therefore, I have no doubt that the binding in question was made from human skin." ${ }^{11}$

With this scientific proof that the book was indeed bound in human skin, UML

7. Berry Boswell Brooks (1902-1976) was born in Senatobia, Mississippi, the son of the local sheriff who moved the family up the road to Memphis when Berry was 12 . After leaving Washington and Lee University, Brooks entered the cotton business in 1922 as a $\$ 25 /$ month clerk. He became a very successful businessman and head of his own company before retiring in 1972. Brooks was famous for his hunting exploits and was the first living American to be inducted into the International Hunting Hall of Fame. He took his family on the first of his four African safaris in 1947 and also hunted across North America from Alaska to Mexico. His trophy animal heads were a major attraction at the Memphis City Museum (later known as the Pink Palace Museum) for many years where they were featured in the Berry B. Brooks African Hall. Brooks made films of his expeditions from the first and by his later years he preferred the camera over the gun and used the images to illustrate the lectures he gave in Memphis. Ann Meeks, "Streetscapes: Epping Way," Commercial Appeal (June 30, 1994), EM3; "Speaking of Pictures...a 14-yearold Big-game Huntress Poses with Her Trophies,” Life 23, no. 13 (Sept. 29, 1947): 18.

8. Edwin Frank, "Note on Provenance of Richeome Book" (June 9, 2015), UML Special Collections case file.

9. Michelle Corbet, "Library's Special Collections Home to a Skin-Crawling Read," The Daily Helms$\operatorname{man} 79$, no. 35 (Oct. 28, 2011): 3, 5 .

10. "Fossil Detectives Using Antibodies to Probe the Past," UCSF News (Feb. 7, 1992), available online at https: / / babel.hathitrust.org/cgi/pt?id=uc1.31378005946077; view=1up;seq=123 [accessed 14 September 2016].

11. Jerold Lowenstein to Diana Crump, copy of letter, May 3, 1985, UML Special Collections case file. 
bought it in October 1986 for the sum of $\$ 500$. Ed Frank recalls that the curator was excited by the new purchase, but there is no evidence in the library newsletters in the following months that any publicity was given to the book's arrival. Nevertheless, the curator and the library director saw it as a means to promote Special Collections and the library, and thus all the instruction classes the department offered for History students on campus were now shown the Richeome book. ${ }^{12}$ When UML moved to a new building in 1994, and Special Collections was relocated from the forbidding depths of the old Brister Library building ${ }^{13}$ to a much more accessible and attractive fourth floor suite, the Richeome book continued to be featured in all instruction sessions and was made available to the increasing number of casual patrons. It was suggested at one point that the book merited a display case in the reading room because of its growing popularity. Not only was it used as a curiosity piece within the department, but it was taken off-campus whenever the curator was invited to speak to groups interested in genealogy, local history, or archives.

By the early 2000s, the department had become one of the more interesting stops on the orientation tour given to University of Memphis freshmen because of the "flesh book." As one guide noted, the book was a "neat fact that students would be interested in, so students will want to come back to check it out and become interested in the resources the library has to offer." ${ }^{14}$ The book had achieved an almost mythic status, and new students felt they needed to visit the library just to find out whether it really existed. Although they could not handle the book, students were offered the opportunity to touch it. ${ }^{15}$ Frank recalled with amusement that some were repelled by it and refused while others would say, "Oh, that's so cool." ${ }^{16}$ The student newspaper fueled the notoriety by regularly featuring a story about the book around Halloween, noting its waxy smell and visible human pores. Visitors often speculated about whose skin was used for the binding, and some of the speculations made their way into the newspaper stories about the book over the years. A history professor on campus suggested it had belonged to a persecuted Huguenot and that the binding was a statement of religious conviction. ${ }^{17}$ This explanation was also mentioned by the director of the university art museum to a

12. Edwin Frank, telephone interview with author, July 12, 2016.

13. The first purpose-built library at the University of Memphis was the John Willard Brister Library, which opened at the then-West Tennessee State Teachers College in 1928. In 1968, most of the library departments moved into a new 12-story tower that adjoined the old building, but Special Collections, which had been created in 1965, remained in the Brister basement until 1994 when the new Ned R. McWherter Library opened. Saundra Williams and Delanie Ross-Plant, "A Thing of Consideration: MSU Libraries, 1912-1970," Campus Tower News, 16, no. 3 (Sept. 1987).

14. Corbet, "Skin-Crawling Read," 5.

15. Justin Kissell, "Flesh-Bound Book on U of M Campus," The Daily Helmsman 72, no. 38 (Oct.26, 2004): 1.

16. Michael Finger, "Q\&A: Ed Frank," Memphis 31, no. 11 (Feb. 2007): 30.

17. Corbet, "Skin-Crawling Read," 3, 5. 
reporter covering an exhibit of exotica that featured the book, as well as the other common idea that a Catholic zealot "left his skin to be used as a book trashing the Huguenots." ${ }^{18}$ Not surprisingly, such reports spread on the Internet, and the book's existence became more widely known. ${ }^{19}$ It was featured on various webpages and in magazines devoted to the obscure and the bizarre. ${ }^{20}$ Not all the writing was of a popular nature, however. A researcher from Baylor University visited UML in 2013 to examine the book as part of a project on anthropodermic bibliopegy. ${ }^{21}$

It is likely that the Richeome book would have continued to be an object of morbid curiosity except that in May 2015 Ed Frank received an offer from Richard Hark of Juniata College, Pennsylvania, to conduct a new test on the book to ascertain whether its binding was really human skin. ${ }^{22}$ Hark, chair of the chemistry department, and Daniel Kirby, an analytical chemist formerly at Harvard University, lead a team, known as the Anthropodermic Book Project, which employs peptide mass fingerprinting (PMF) to test books supposedly bound in human skin. PMF can be used to identify mammalian sources of collagen including skin, the source of parchment. By analyzing the amino acid sequences in proteins for their unique mixture of peptides, researchers can detect species-specific markers that distinguish human parchment from other mammalian sources. ${ }^{23}$ Kirby had already used PMF to determine that books reputed to have an anthropodermic binding in Harvard's Law School Library and at Juniata were in fact bound in sheepskin, ${ }^{24}$ while proving that others at Harvard's Houghton Library and the Historical Medical Library of the College of Physicians of Philadelphia were indeed bound with human skin. ${ }^{25}$ The team wants to compile an authoritative list of human skin books and, to that

18. Michael Finger, “Cleaning Out the Closet,” Memphis Flyer 431 (May 22-28, 1997): 41.

19. Marcus Harbert, "Bound in Human Skin" (Sept. 26, 2006), available online at http: / EzineArticles.com/expert/Marcus_Harbert/23040 [accessed 13 September 2016]; “The Book of Human Flesh,” Mississippi Library Commission Blog (Oct. 24, 2014), available online at http: / / mlcref.blogspot. com/2014/10/the-book-of-human-flesh.html [accessed 13 September 2016].

20. An example is Christian Saunders, “The Word Made Flesh," Fortean Times 223 (Mar. 2008): 42-46, which featured the book. A photograph of Frank holding the book is still used to illustrate stories about human skin book binding online.

21. See Harrison, "On the Binding."

22. Richard Hark to Edwin Frank, e-mail message, June 1, 2015, UML Special Collections case file.

23. "Analyzing Alleged Human Skin Books Via Peptide Mass Fingerprinting," The Anthropodermic Book Project, available online at https: / / anthropodermicbooks.org/ [accessed 15 September 2016]. 24. Karen Beck, “Old Books, New Technologies, and 'The Human Skin Book' at HLS,” Et Seq.: The Harvard Law School Blog (Apr. 3, 2014), available online at http: / / etseq.law.harvard.edu/2014/04/852-rareold-books-new-technologies-and-the-human-skin-book-at-hls / [accessed 15 September 2016]; Jacob Gordon, "In the Flesh? Anthropodermic Bibliopegy Verification and its Implications," RBM: A Journal of Rare Books, Manuscripts, and Cultural Heritage 17 (Fall 2016): 124-27, 130-32; Simon Davis, "The Quest to Discover the World's Books Bound in Human Skin,” mental_floss (Oct. 19, 2015), available online at http:// mentalfloss. com/article/ 70048/ quest-discover-worlds-books-bound-human-skin [accessed 15 September 2016].

25. Heather Cole, "The Science of Anthropodermic Binding," Houghton Library Blog (June 4, 2014), available online at http:/ / blogs.harvard.edu/houghton/2014/06/04/caveat-lecter/ [accessed 13 September 2016]; Beth Lander, "Welcome to This Inaugural Edition of Fugitive Leaves...," Fugitive Leaves Blog (Oct. 1, 2015), available online at www.collegeofphysicians.org/histmed/welcome/ [accessed 15 September 2016]. 
end, contacts libraries and museums across the country to request permission for their books to be tested. Since the evidence that the books are purportedly bound in human skin is based mostly on hearsay and older, more primitive, scientific testing, the team believed institutions would welcome the opportunity to have a definitive answer. However, they found that some librarians have been reluctant simply because attitudes to such objects have changed in the last century, and libraries and museums tend not to acknowledge they possess these items and certainly no longer display them. ${ }^{26}$

The reaction at UML to Hark's inquiry was mostly positive. Ed Frank believed it was important to settle whether the Richeome book was what it was claimed to be, but he sought the views of the library's cataloging and preservation librarians before agreeing to have the book tested. As scholars of the book and book culture, the catalogers were enthusiastic, but the preservation librarian was more cautious. He was concerned, naturally, about possible damage during the sampling process, but he also questioned whether an object that had been handled so extensively over the years could supply an uncontaminated sample. ${ }^{27}$ Reassured that the samples required were minute and would be taken from areas of the binding that should not have been exposed to generations of student hands, the book was delivered to a laboratory on campus where the sampling could be done under the stringent conditions the testing team required..$^{28}$ The three samples were then sent to Massachusetts at the end of June $2015 .^{29}$

Two weeks later, Dan Kirby e-mailed that the book did not have an anthropodermic binding but one of sheepskin, like many other supposed "human skin books." ${ }^{30}$ The report that followed noted that all of the samples taken from foldovers on the head and tail of the spine were identified as "sheep and not human or any common binding material such as cattle, deer or goat." ${ }^{31}$ Yet, despite an announcement to the campus community in January 2016 that UML no longer had a "human skin book," ${ }^{32}$ and informing the guides for the freshmen orientation tours of the test results, Special Collections continues to have people ask after it. As Ed Frank remarked, the story about the book acquired its own momentum, and it will take a long time for that story to die. ${ }^{33}$

\footnotetext{
26. Davis, "Quest to Discover."

27. Edwin Frank to Mark Danley, Linde Brocato, and Gerald Chaudron, e-mail message, June 3, 2015; Edwin Frank to Richard Hark, email message, Sept. 6, 2015, UML Special Collections case file.

28. Omar Skalli to Edwin Frank, e-mail message, June 22, 2015, UML Special Collections case file.

29. Dan Kirby to Edwin Frank, e-mail message, June 26, 2015, UML Special Collections case file.

30. Dan Kirby to Edwin Frank, e-mail message, July 12, 2015, UML Special Collections case file.

31. Dan Kirby Analytical Services, "Analytical Report" (Sept. 2, 2015), UML Special Collections case file.

32. University of Memphis Libraries, Between the Stacks 5 (Jan. 2016).

33. Edwin Frank, telephone interview with author, July 12, 2016.
} 


\section{A Question of Ethics}

As the Anthropodermic Book Project team discovered, there is some wariness among institutions that hold books with supposedly human skin bindings to acknowledge they possess them. The team found that, even among those who discover their books are not anthropodermic, little publicity is given to the findings. ${ }^{34}$ In his study of anthropodermic bibliopegy, Jacob Gordon pointed out that the ethical considerations surrounding these objects have become increasingly important, and libraries should be more sensitive about handling such culturally sensitive materials. ${ }^{35}$ UML has always been very open about owning the Richeome book because it was regarded as an important asset for outreach purposes, but it took many years for the ethical questions regarding the handling and display of the book to even become a consideration. However, the reasons behind Ed Frank's decision finally to stop displaying the Richeome book were more complicated than a simple desire to be respectful of an individual's bodily remains.

Already retired by the time the test results were known, Frank had mixed feelings about the outcome. He was well aware that the university was not one of the prestigious institutions of the East Coast, for example, for which one book bound in human skin was of little significance, because their archives hold a wealth of materials that attract researchers from all over the world. While Special Collections has important collections on the history of Memphis and West Tennessee, holding one of the few confirmed examples of anthropodermic bibliopegy in the country gave UML recognition beyond its region. As a historian and archivist, Frank was thus disappointed that UML could no longer claim to hold an interesting item like a book bound in human skin. Other staff in the library shared this disappointment, and there were questions about what might replace it to continue to draw in patrons.

Yet Frank was also relieved that the department would in future be known for its other materials, not just the book. ${ }^{36}$ Indeed, as the Richeome book became increasingly notorious among the students, Frank's doubts grew about the propriety of displaying it to the classes and casual visitors who came to Special Collections. $\mathrm{He}$ noted that very few of the visiting classes were about religion or French history, and thus the students were mostly uninterested in the content of the book. Its use by scholars was almost nil. Frank also came to question whether it was ethical to handle an object-a relic — representing a practice now considered almost barbaric so casually. He concedes this change of view came quite late, for he had not given

34. Davis, "Quest to Discover." By October 2015, the Project had tested 22 books, of which 12 were confirmed as having anthropodermic bindings.

35. Gordon, "In the Flesh?" 133.

36. Edwin Frank, telephone interview with author, July 12, 2016. The librarians at Juniata felt the same way. Davis, "Quest to Discover"; Gordon, "In the Flesh?" 118. 
the matter much thought before the early 2000s. ${ }^{37}$ Although archives and libraries hold materials that are culturally sensitive because of their descriptions and illustrations of controversial ideas or events, what the object is made of seldom provokes controversy. In contrast, museums have become careful about displaying human remains in their collections because of possible conflicts with the values of their patrons. For some, the remains are viewed as people rather than objects; thus it is unethical to exhibit them. There is an acknowledgement that, while the role of museums is to educate, and ethical standards continue to evolve, cultural sensitivity is vital. Yet there is also an awareness that exhibits of mummified bodies and other human remains are popular with museum visitors, ${ }^{38}$ as Frank himself had experienced with the "human skin book."

It is not surprising that some libraries holding books with anthropodermic bindings continue to allow them to be highlighted because they draw attention that may possibly be parlayed into more patrons for their collections. ${ }^{39}$ The director of the University of Georgia's Hargrett Library claimed, in reference to such a book in her library, that "we are more than the book bound in human skin," but she also acknowledged that students "don't relate to dry, by-the-numbers historical accounts as well as they do to these more personal artifacts." ${ }^{30}$ However, those institutions that appear to treat such books as mere curiosities or allow publicity that could be interpreted as flippant, can suffer criticism that calls into question their ethical standards. ${ }^{41}$ Frank recalled that no one in the library or on campus had suggested the book should not be displayed, and, apart from the occasional "generalized distaste" expressed about the binding itself, the ethics of owning or handling such an object had never been raised with him. For many years, he simply accepted the view of his predecessors that it was a useful outreach tool for the department. ${ }^{42}$

Frank's doubts about whether to continue the practice seem to have been fueled mainly by the fact that, while the book drew students to Special Collections, almost

37. Edwin Frank, telephone interview with author, July 12, 2016; Edwin Frank, interview with author, December 5, 2016.

38. Andromache Gazi, "Exhibition Ethics: An Overview of Major Issues," Journal of Conservation and Museum Studies 12, no. 1 (2014): 1-10, available online at www.jcms-journal.com/articles/10.5334/ jcms.1021213/ [accessed 16 September 2016].

39. Cole, "Anthropodermic Binding"; Taryn Martinez, "In a Literal Bind: Hay Has Books Bound with Anthropodermic Leather," Brown Daily Herald (Jan. 31, 2006): 1, 4, available online at www.browndailyherald.com/2006/01/31/in-a-literal-bind/ [accessed 15 September 2016]; Gordon, "In the Flesh?" 121, 122,130 .

40. Mitchell Graham, "Hargrett Library: 'More Than the Book Bound in Human Skin,'” The Red \& Black (Feb. 8, 2001), available online at www.redandblack.com/variety/hargrett-library-more-than-the-bookbound-in-human-skin/article_484abcbb-7fe3-5f75-8d8a-930f5a70197d.html [accessed 15 September 2016].

41. Paul Needham, "A Binding of Human Skin in the Houghton Library: A Recommendation" (June 25,2014 ), available online at www.princeton.edu/ needham/Bouland.pdf [accessed 15 September 2016].

42. Edwin Frank, telephone interview with author, July 12, 2016; Edwin Frank, interview with author, December 5, 2016. 
none of these students returned to use the department's resources for their classes. Though his ethical qualms were important, they were outweighed by his concern that the notoriety surrounding the book was now harming the department's image as a serious archival repository. By the early 2010s, he had asked the freshmen orientation guides to stop referring to the book during their tours, and he directed that visitors only be shown a photograph of the book rather than the real thing. Frank admitted that the photograph was a concession to the continued fascination with the book, but he argued that it would be unfair to those who had taken the trouble to visit the department not to show them something and to use the opportunity to talk about the mission of the department. He just hoped that, by not promoting the book in any way or making the actual object accessible, public interest in it would fade. ${ }^{43}$

Just as with the museum community, archives and libraries face a dilemma when they possess an object linked to human remains, and UML's experience reflects this dilemma. The principal, perhaps only, reason the Richeome book was purchased was because it would draw attention to Special Collections. The fact that the university did not offer courses for which the content of the book was particularly useful was irrelevant. Cultural institutions have historically sought objects that make them stand apart from others. UML Special Collections was a relatively small library archive in a mid-sized Southern college, and the archive had only been in existence for 20 years when the Richeome book was acquired. For much of that time, the department was encouraged to collect materials that were diverse and interesting as befitting an older and larger institution, and thus the purchase of the Richeome book was a coup that was exploited as much as possible for many years. Certainly, the department endeavored to make sure those who saw the book or wrote about it were aware of its content, but most of the publicity tended to focus on the macabre nature of the binding. The department has grown significantly since the Richeome book was acquired, and it has become more focused on its mission of telling the story of Memphis and the surrounding region. In a way, the "skin book" had become an impediment to furthering that mission, and thus Ed Frank's successor as curator was not unhappy that the tests came back negative. Indeed, the decision to allow the testing to be done was made primarily in the interests of scholarship, because the book had been retired from public view for some time.

The ethical questions about owning and handling the book had been limited to Ed Frank himself, in his capacity as curator. He made the decision to withdraw the book without considering the need to consult anyone else in the library or on

43. Edwin Frank, telephone interview with author, July 12, 2016; Edwin Frank, interview with author, December 5, 2016. 
campus, since no one in the university administration had shown any interest in the book in the years he had been curator. ${ }^{44}$ Yet the possibility that the new test might confirm it as an anthropodermic binding led to some discussion of the ethical considerations among the small number of librarians Frank consulted after the test was first suggested in May 2015. One question was whether a positive test result would require a reexamination of how the book was regarded within the library, and would that necessitate a new policy recognizing the unique cultural challenges of holding such an object. Developing policy would be difficult, because little guidance was provided by professional organizations in archives or libraries. The group did agree that the book would not be brought out of retirement if the test was positive. The consensus was that the book represented a binding practice that was no longer acceptable, and using the book as a curiosity to attract visitors was also an outdated practice. But the discussion did not proceed much beyond that point as the test result was awaited, and then the negative result effectively put an end to it.

The story of the Richeome book's human skin binding will take time to die, as Frank suggested. Visitors to Special Collections continue to ask about it from time to time; and, after the book's history is explained to them, some are disappointed that what they heard is untrue. The University of Memphis student newspaper highlighted the book again in its Halloween issue in 2016, but the article was primarily about the fact that it was not bound in human skin after all. ${ }^{45}$ During the interview for the story, the curator was asked if he was sorry that UML no longer had a book bound in human skin and whether he had considered not revealing the fact. His answer was "no" to both questions, and he explained that its true story is fascinating enough and that the department's reputation had everything to gain by telling that story. In a way, the story of the Richeome book at the University of Memphis had come full circle: this obscure French religious tract is returning to obscurity, and Special Collections is moving on without it.

44. Edwin Frank, interview with author, December 5, 2016.

45. Emily Okins, "Six Spooky Sights on School," The Daily Helmsman 84, no. 38 (Oct. 28, 2016): 5. 